\title{
Antarctic Fish as a Global Pollution Sensor: Metals Biomonitoring in a Twelve-Year Period
}

\author{
Alessandro Marrone ${ }^{1 \dagger}$, Daniele La Russa ${ }^{2 \dagger}$, Elvira Brunelli ${ }^{1}$, Gianfranco Santovito ${ }^{3}$, \\ Mauro Francesco La Russa ${ }^{1}$, Donatella Barca ${ }^{1}$ and Daniela Pellegrino ${ }^{1 *}$
}

${ }^{1}$ Department of Biology, Ecology and Earth Sciences, University of Calabria, Rende, Italy, ${ }^{2}$ Department of Pharmacy, Health and Nutritional Sciences, University of Calabria, Rende, Italy, ${ }^{3}$ Department of Biology, University of Padova, Padova, Italy

\section{OPEN ACCESS}

Edited by:

Pablo Andres Evelson,

University of Buenos Aires, Argentina

Reviewed by:

Carlos M. Luquet,

Consejo Nacional de Investigaciones Científicas y Técnicas (CONICET),

Argentina

Carlo C. Lazado

Fisheries and Aquaculture Research

(Nofima), Norway

*Correspondence:

Daniela Pellegrino

danielapellegrino@unical.it

${ }^{+}$These authors have contributed equally to this work

Specialty section:

This article was submitted to

Cellular Biochemistry,

a section of the journal

Frontiers in Molecular Biosciences

Received: 14 October 2021 Accepted: 17 November 2021 Published: 09 December 2021

Citation:

Marrone A, La Russa D, Brunelli E, Santovito G, La Russa MF, Barca D and Pellegrino D (2021) Antarctic Fish as a Global Pollution Sensor: Metals Biomonitoring in a Twelve-Year Period.

Front. Mol. Biosci. 8:794946.

doi: 10.3389/fmolb.2021.794946
Antarctica represents a unique natural laboratory for ecotoxicological studies as it is characterized by low internal pollutants emissions but high external contamination levels. Indeed, warm temperatures promote pollutant evaporation (low latitudes), while cool temperatures (high latitudes) promote its deposition from the atmosphere on land/water. Metals are the most important pollutants in ecosystems and represent a serious and global threat to aquatic and terrestrial organisms. Since 2000, the risks posed by metals have led many States to ratify protocols aimed at reducing their emissions. Endemic Antarctic organisms represent excellent bioindicators in order to evaluate the efficacy of global measures adopted to mitigate pollutants release into the environment. In this study (supported by PNRA18-00133), we estimated the metals contamination levels and the metallothionein-1 expression in liver samples of two Antarctic fish species, the icefish Chionodraco hamatus and the red-blooded Trematomus bernacchii, collected in the same area during 2002 and 2014. The chosen area is located in the Ross Sea, a unique area as it is also isolated from the rest of the Southern Ocean. The analysis of contamination trends throughout this period showed, in both species, a significant increase over time of metals bioaccumulation and metallothionein-1 expression. In addition, our result clearly indicated that the detoxifying ability of the two organisms analyzed greatly differs, probably due to haemoglobin presence/absence. Our work represents an important early step to obtain valuable information in conservation strategies for both Antarctic and non-Antarctic ecosystems.

Keywords: global pollution, antarctic fish, metals biomonitoring, metallothionein, bioaccumulation

\section{INTRODUCTION}

The Antarctic continent is the southernmost part of the planet, but geographic isolation does not protect it from the negative impact of human activities. Long-range atmospheric transport is the main means by which contaminants reach Antarctica, as the Antarctic Polar Front's presence strongly decreases the pollutant marine transport. Due to the low internal pollutant emissions but high external contamination levels, Antarctica is an excellent sensor for global pollution trends. Monitoring such levels is needed to evaluate the efficacy of global measures adopted to mitigate pollutant release into the environment. In addition, an effective control strategy is required for a better understanding of how they are distributed globally.

Metals are natural constituents of the earth's crust and, through natural phenomena, are continuously released into the biosphere. Numerous anthropogenic activities have drastically 
altered their geochemical cycles and biochemical balance on a global scale. In recent decades, metals have polluted the environment from the poles to the tropics and from the mountains to the depths of the oceans (Cimboláková et al., 2020). These substances accumulate in Arctic and Antarctic areas where they have been identified in significant amounts despite the pollution sources being very distant. Warm temperatures favor pollutant evaporation (tropical and subtropical land surface), while cool temperatures (high latitudes) favor its deposition from the atmosphere on land/ water (Wania and Mackay, 1996; Noyes et al., 2009). Climate change and global warming could enhance the transport/deposit of contaminants in polar areas and may be particularly problematic for species living at the edge of their physiological tolerance range where acclimation capacity may be limited (Noyes et al., 2009). Despite the polar environment vulnerability, studies on these territories are scarce and dated, though it has clearly emerged that trace metal contamination in organisms of the Southern Ocean are high in comparison to those from other oceans (Bargagli, 2000, 2008; Sanchez-Hernandez, 2000; Beltcheva et al., 2011; Roche et al., 2019).

In the present paper, we will focus on the metal's contamination trend in Antarctica over a long period of time (12 years) using as bioindicators two fish species, the icefish Chionodraco hamatus and the red-blooded Trematomus bernacchii, collected in the same area during 2002 and 2014. The fish species are widely used as a bioindicator organism of Antarctic ecosystems due to their ability to accumulate pollutants, ecological relevance and physiological adaptations (Santovito et al., 2012a; Bargelloni et al., 2019; Garofalo et al., 2019; Tolomeo et al., 2019; Ansaloni et al., 2021). The selected area is located in the Ross Sea, which since 2017 has become the largest marine protected area in the world. The Ross Sea is located in a deep bay in southern Antarctica and is the largest ecosystem on the Antarctic continent, containing unique features and a level of biodiversity superior to other polar areas. The main feature that makes this area so unique is its physical conformation. In fact, this area remains isolated from the rest of the Southern Ocean because most of its surface water remains within its area and mixes little with the external water. This isolation ensures that the fish and larvae present do not disperse and mix with other organisms. Thus, not only is Antarctica a unique place for its marine fauna, but the fauna present in the Ross Sea has its characteristics that are only found there and nowhere else (Cummings et al., 2021).

Fish are widely recognized as the most relevant model for pollution monitoring in aquatic ecosystems (Van der Oost et al., 2003). In particular, Antarctic organisms, due to their endemic and highly adaptation ability to extreme conditions, represent excellent bioindicators to analyze the trend of metal bioaccumulation over time. In fish, metals can enter the body through the gills or the intestinal wall and then distributed to the tissues (Tchounwou et al., 2012). Both essential and non-essential metals can exert toxic actions, whereby intracellular metals levels are highly regulated by metal-binding proteins such as metallothioneins (Wang et al., 2014; Kan et al., 2019). Metallothioneins (MTs), a family of highly conserved cysteinerich proteins evolved in all eukaryotes from unicellular to vertebrate (Formigari et al., 2010; Santovito et al., 2012b, 2015, 2021), are involved in several cellular processes and play a key role in cellular protection from actions of harmful agents such as metal and reactive oxygen species (Santovito et al., 2008; RuttkayNedecky et al., 2013; Wang et al., 2014; Kan et al., 2019).

We choose the liver as a target organ since it is implicated in the regulation of metabolic pathways, homeostasis, and detoxification and it may represent a good indicator of bioaccumulation and detoxification after metal exposure $(\mathrm{Qu}$ et al., 2014; Macirella et al., 2016, 2019; Macirella and Brunelli, 2017). The objective of the current research was, on the one hand, to monitor the fragile Antarctic ecosystem and, on the other hand, to obtain critical information on the global trend of metal pollution to drive the conservation strategies for the Antarctic and non-Antarctic ecosystems.

\section{MATERIALS AND METHODS}

\section{Animals}

Adult specimens of two species of benthonic fish, the red-blooded Trematomus bernacchii Boulanger (Notothenidae) and the icefish Chionodraco hamatus Lönnberg (Channichthydae), were caught using nets at depths of 80 and $150 \mathrm{~m}$ during the XVII (2001-2002) and XXIX (2013-2014) Italian Antarctic expeditions in the Terra Nova Bay, Ross Sea, Antarctica $\left(74^{\circ} 41^{\prime} 42^{\prime \prime} \mathrm{S}, 164^{\circ}\right.$ $07^{\prime} 23^{\prime \prime} \mathrm{W}$ ). Target fish are endemic and non-migratory species, and identification was based on descriptions of Fisher and Hureau (1985). The sampling, performed in a 12-years range, was operated so as to ensure a broad geographical representation and adequate homogeneity, according to the highest standards in the use of these organisms for biomonitoring activities. We used 5 adult specimens of both sexes for each species: -2002- T. bernacchii $294.2 \pm$ $58.08 \mathrm{~g}, 28.6 \pm 5.36 \mathrm{~cm}$; C. hamatus $396 \pm 37.81 \mathrm{~g}, 36.1 \pm 2.31 \mathrm{~cm}$; -2014- T. bernacchii $298.6 \pm 53.89 \mathrm{~g}, 28.2 \pm 5.71 \mathrm{~cm}$; C. hamatus $389.4 \pm 29.94 \mathrm{~g}, 35.62 \pm 2.07 \mathrm{~cm}$. After capture and relaying, each animal was anesthetized with ethyl 3-aminobenzoate methanesulfonate salt $(0.065 \mathrm{~g} / \mathrm{L}$; Sigma; St. Louis, MO, United States) and then weighed. Samples of both liver (2002 and 2014) and plasma (2014) properly stored (frozen in liquid nitrogen and stored at $-80^{\circ} \mathrm{C}$ ) were obtained from previous Antarctic expeditions and used for ex novo analysis. Correctly stored plasma samples from 2002 could not be found.

\section{Biomonitoring of Pollutants}

We estimated the contamination levels of 10 metals: strontium (Sr), chromium $(\mathrm{Cr})$, cobalt $(\mathrm{Co})$, nickel $(\mathrm{Ni})$, zinc $(\mathrm{Zn})$, arsenic (As), selenium (Se), molybdenum (Mo), cadmium (Cd), and lead $(\mathrm{Pb})$. The liver content of each metal was determined by a quadrupole Inductively Coupled Plasma-Mass Spectrometer (ICP-MS, PerkinElmer, model Elan DRCe), by means of solution nebulization. Before analysis, samples were mineralized by acid digestion using a microwave oven. The liver samples were dried under a laminar flow hood for $24 \mathrm{~h}$ and weighted into digestion vessels. After adding $10 \mathrm{ml}$ of ultrapure $\mathrm{HNO}_{3}$, digestion vessels were capped and placed into a 12-position turntable CEM (Mars 5) microwave oven. A ramped temperature control program was 

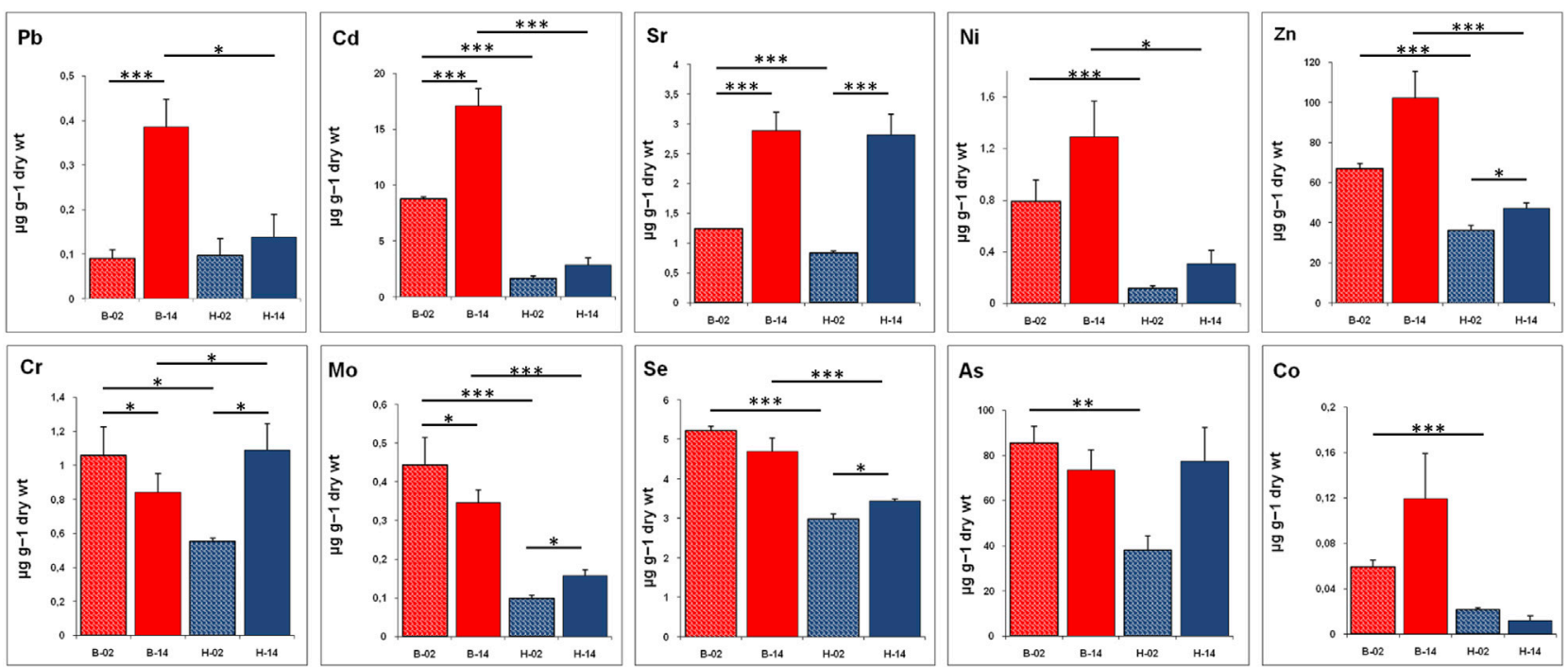

FIGURE 1 | Bioaccumulation level of metals (Pb, Cd, Sr, Ni, Zn, Cr, Mo, Se, As, and Co) in liver of T. bernacchii (B) and C. hamatus (H) in 2002 (02) and 2014 (14). Data are expressed as means $\pm \mathrm{SE}(\mathrm{n}=5)$; statistical differences were evaluated by two-way Anova followed by Bonferroni's multiple comparison tests $\left({ }^{*} p<0.05\right.$; ${ }^{* \star} p<$ $\left.0.025 ;{ }^{* \star *} p<0.005\right)$.

applied: ramp to $180^{\circ} \mathrm{C}$ for $15 \mathrm{~min}$, followed by $15 \mathrm{~min}$ cooling down. The temperature was monitored in a control vessel by an armored fiber-optic temperature control probe, and the pressure was monitored by an internal pressure control system. After cooling down, microwave vessels were vented, and extractions were diluted to a final volume of $100 \mathrm{ml}$ using Milli-Q water. Finally, the solution is preserved at a temperature of $4^{\circ} \mathrm{C}$. In each analytical sequence, procedural blanks and reference materials were included. The precision and accuracy of the applied analytical method were estimated on Certified Reference Material (CRM), Tort 2 (lobster hepatopancreas).

\section{Western Blotting Analysis}

Samples of cell-free liver extract containing $50 \mu \mathrm{g}$ of proteins were heated for $5 \mathrm{~min}$ in Laemmli buffer (Sigma, St Louis, MO, United States), separated by SDS PAGE using 15\% gel in a Mini trans-blot transfer cell, and then transferred to nitrocellulose membrane using a mini trans-blot (Bio-Rad Laboratories, Hercules, CA, United States). The membrane was blocked with TBS-T buffer containing $5 \%$ non-fat dry milk. For immunodetection, the blots were incubated overnight at $4^{\circ} \mathrm{C}$ with monoclonal mouse anti-MT antibody (Enzo Life Sciences) diluted in TBS-T buffer containing 5\% BSA. The blots were then washed and incubated with a peroxidase linked secondary antibody (Santa Cruz). Protein loading was verified using anti- $\beta$-actin antibody (Santa Cruz). Immunodetection was performed by using an enhanced chemiluminescence kit, and autoradiographs were obtained by exposure to X-ray Films. Immunoblots were digitalized, and the densitometric analysis of the bands obtained was carried out using WCIF ImageJ based on 256 grey values ( $0=$ white; $256=$ black). Quantification of the bands was obtained by measuring (5 times on each band) the mean optical density of a square area after the background area was subtracted. The results of absorbance measurements and the grey values obtained from the densitometric analysis were expressed as mean \pm SE of five determinations for each sample.

\section{Measurement of Plasma Oxidative Status}

Plasma oxidative status was determined by using photometric measurement kits and a free radical analyzer system with a spectrophotometric device reader (FREE Carpe Diem, Diacron International, Grosseto, Italy), which are routinely used in our laboratory in both human and animal models (Brunelli et al., 2017; La Russa et al., 2017; La Russa et al., 2019; Russa et al., 2019; La Russa et al., 2020; La Russa et al., 2021; Perri et al., 2021). Plasma oxidative stress was assayed using a Diacron-reactive oxygen metabolite (dROM) test. Results are expressed in Carratelli Units (UC; $1 \mathrm{UC}=0.8 \mathrm{mg} / \mathrm{L}$ of hydrogen peroxide). Total plasma antioxidant capacity was assayed using a biological antioxidant capacity (BAP) test. Results are expressed in $\mu \mathrm{mol} / \mathrm{L}$ of the reduced ferric ions.

\section{Statistical Analysis}

Data were analyzed using the GraphPad/Prism version 5.01 statistical software (SAS Institute, Abacus Concept, Inc., Berkeley, CA, United States). Statistical differences were examined using twoway Anova followed by Bonferroni's multiple comparison tests, and the significance level was considered at $p<0.05$. Results are expressed as the mean \pm standard error (SE).

\section{RESULTS}

\section{Metals Bioaccumulation}

In the considered period, in the liver of T. bernacchii, a significant increase has been detected for $\mathrm{Cd}, \mathrm{Sr}$, and $\mathrm{Pb}$ (Figure 1). It is also 

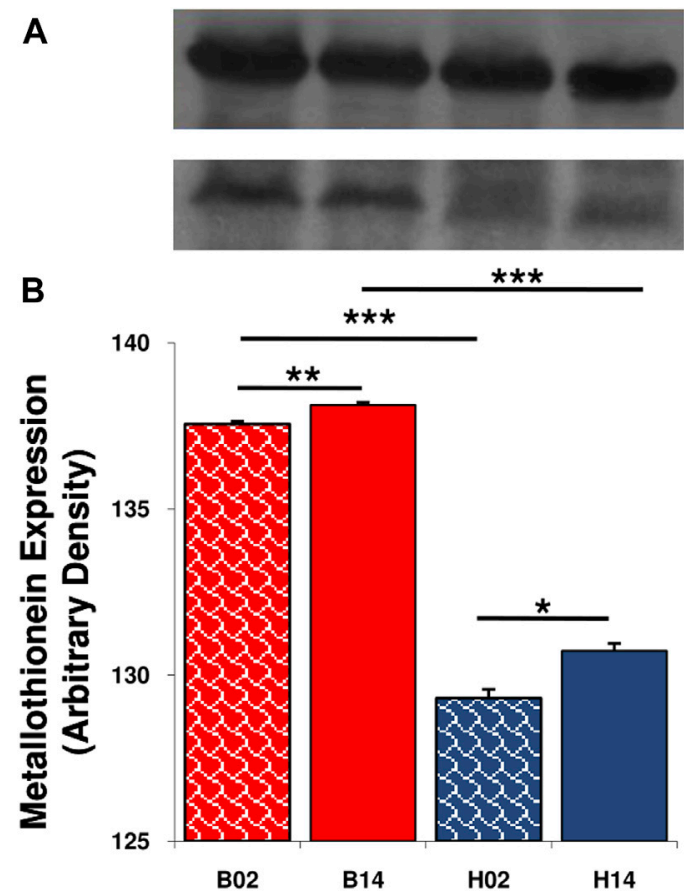

FIGURE 2 | Expression level of metallothionein in liver of $T$. bernacchii and C. hamatus in 2002 (02) and 2014 (14). (A) Representative immunoblots of metallothionein and $\beta$-actin. (B) Densitometric analysis of protein levels; data are means \pm SEM of seven determinations for each animal $(n=5)$; statistical differences were evaluated by two-way Anova followed by Bonferroni's multiple comparison tests $\left({ }^{*} p<0.05\right.$; ${ }^{* \star} p<0.025$; $\left.{ }^{\star \star \star} p<0.005\right)$.

interesting to underline the increase in $\mathrm{Zn}, \mathrm{Ni}$, and $\mathrm{Co}$ concentrations, although the differences are not statistically significant. Moreover, in this species, a significant decrease in liver concentration has been detected for Mo and $\mathrm{Cr}$, whereas Se and As decrease insignificantly. In C. hamatus we recorded an increase, from 2002 to 2014, of all tested metals in the liver tissue except for Co, which shows a slight decrease from the low initial value (Figure 1). Interestingly, in this hemoglobinless organism, the bioaccumulation levels are much lower than in the redblooded species $T$. bernacchii, especially in the first sampling carried out in 2002. The increase in hepatic concentrations is significant for Sr, Se, Mo, Cr, and $\mathrm{Zn}$. A great increase in $\mathrm{Sr}, \mathrm{Cr}$, and As contents is particularly evident as the initial value is doubled, reaching levels comparable to the values found in $T$. bernacchii.

\section{Metallothionein Expression}

Comparing samples collected in 2002 and 2014, we observed a significant increase in metallothionein-1 expression in both species (Figure 2). The levels were always higher in the redblooded species $T$. bernacchii than in the icefish C. hamatus.

\section{Plasmatic Oxidative Status}

The analysis of the plasmatic oxidative balance showed some differences between the two species. The icefish showed higher levels of hydroperoxides, although this difference is not statistically significant. A statistically significant difference was found in the levels of antioxidant capacity, once again in favor of C. hamatus (Figure 3).

\section{DISCUSSION}

This research aims to employ Antarctica as a global pollution sensor by using its endemic organisms as bio-indicators. Despite their remoteness, the polar regions are increasingly subject to anthropogenic contamination. The high degree of endemism and the unique eco-physiological adaptations make Antarctic species particularly sensitive to contaminants (Bargagli, 2008; Garofalo et al., 2009). The measure of metals that reach isolated and putatively uncontaminated areas as the polar zones allows us to evaluate the risk of such substances that travel across the world and accumulate in ecosystems. In the last few years, several studies have concerned the metal contamination in various organic and inorganic matrices of the Antarctic continent (Koppel et al., 2019; Potapowicz et al., 2019; Pilcher et al., 2020; Webb et al., 2020; Xu et al., 2020). Although the structure and dynamics of Antarctic ecosystems make them valuable tools for assessing past and current global pollutant levels, almost no (contamination) data before 2000 is available, and very few are available for the years 2000-2015 (Bargagli, 2000, 2008; Twining and Baines, 2013; Vodopivez et al., 2015).

To fill this gap, we have chosen to analyze the metal contamination trends in 12 years (in 2002 and 2014) and evaluate both bioaccumulation and some physiological responses, such as metal homeostasis and antioxidant defenses of model organisms. The use of organisms as a biological indicator to determine trace metal pollution is particularly useful because organisms concentrate metals from the environment, but they may also represent a moving timeaveraged value for the metal biological availability.

The first outcome that appears noticeable by an overall analysis of our results is that the two fish, although both are benthic species (Eastman, 1993), show different levels of metal bioaccumulation, specifically the red blooded species $T$. bernacchi exhibit higher levels with respect to the icefish $C$. hamatus, and this is particularly evident in the 2002 sampling. It is known that the tissue levels of different metals vary as a result of different uptake pathways, and metals concentration exhibited a large variability in the same tissue according to the species (Terra et al., 2008; Bervoets et al., 2013; El-Moselhy et al., 2014; Mahboob et al., 2016). We can suppose that the ecological and behavioral features of species might play a role in the processes of uptake and accumulation of the metals by organisms, and also local environmental might influence the different patterns observed in the two considered species. Moreover, we must consider that the two species analyzed show profound physiological differences due to the presence/absence of hemoglobin and the different redox balance levels showed.

In the environment, organisms are simultaneously exposed to multiple metals and their absorption can vary due to additive, antagonistic or synergistic phenomena (Tchounwou et al., 2012). Indeed, essential metals are important constituents of both oxidative stress-related enzymes and metalloenzymes involved 

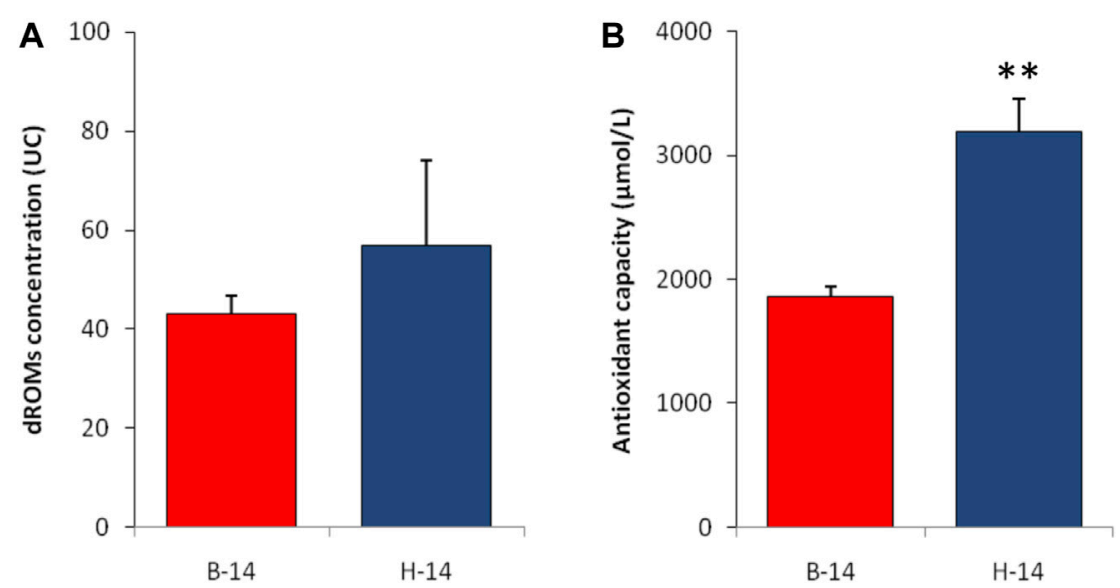

FIGURE 3 | Plasmatic values of reactive oxygen metabolite (A) and biological antioxidant capacity (B) test in liver of T. bernacchii (B) and C. hamatus (H) in 2014 (14). Data are expressed as means $\pm \mathrm{SE}(\mathrm{n}=5)$; statistical differences were evaluated by two-way Anova followed by Bonferroni's multiple comparison tests ( $\left.{ }^{\star \star} p<0.025\right)$.

in hemoglobin formation (Tchounwou et al., 2012). Our results showed a significant increase over time in the bioaccumulation of many metals and, in particular, $\mathrm{Pb}, \mathrm{Cd}, \mathrm{Sr}, \mathrm{Ni}$, and $\mathrm{Zn}$ showed a remarkable growth trend in bioaccumulation in both species analyzed. In small amounts, $\mathrm{Pb}$ occurs naturally in the environment, however, anthropogenic activities contribute to the high release of this dangerous toxicant. In particular, the fossil fuel burning and the production of leadacid batteries and paint represented the main source of lead pollution. Human exposure to lead represents a serious health problem as it is the most systemic toxicant that affects several organs in the body including the kidneys, liver, central nervous system, hematopoietic system, endocrine system, and reproductive system (Flora et al., 2012; Wani et al., 2015). In recent decades, many States ratified protocols aimed at decreasing emissions and the lead release has been significantly reduced at the industrial level, although the most marked effect was achieved with the elimination of $\mathrm{Pb}$ in gasoline. In this research, we have focused on a very important period of time to evaluate the environmental effect of the ban on lead from gasoline as 2002 is the year in which all states have effectively adhered to this protocol. Despite the effective and significant reduction of emissions, our results clearly demonstrate that lead bioaccumulation has considerably grown in both species analyzed, highlighting that global pollution mitigation measures take extremely long time. However, we must not forget that this increase in $\mathrm{Pb}$ bioaccumulation detected in our Antarctic organisms could also derive from remobilization of both natural and industrial $\mathrm{Pb}$ due to increased surface melt duration and extent caused by increased temperature over the last years (Ndungu et al., 2016). In addition to Pb, also the other nonessential metals $\mathrm{Cd}$, and $\mathrm{Sr}$ showed significant bioaccumulation in both fish species analyzed. In particular, the Sr levels detected in 2014 are significantly higher than in 2002 also in the icefish, which, compared to the red-blooded species, generally shows lower levels of bioaccumulation. Concerning the Cd levels, it is important to mention that this metal is characterized by a high accumulation coefficient and high chemical similarity to $\mathrm{Zn}$, thus $\mathrm{Cd}$ easily enters various enzymatic reactions instead of $\mathrm{Zn}$ altering biochemical processes (Cimboláková et al., 2020). In fish, $\mathrm{Pb}, \mathrm{Cd}$, and $\mathrm{Sr}$ pollution are particularly serious as their assimilation mainly occurs through the chloride cells of gill epithelium, since all three of these non-essential metals present high affinity with calcium uptake mechanisms (Olsson et al., 1998; Beltcheva et al., 2011).

The analysis of $\mathrm{Ni}$ and $\mathrm{Zn}$ levels showed a consistent increase from 2002 to 2014 in our bio-indicator organisms. Ni and $\mathrm{Zn}$ are essential micro-nutrients that are required for various biochemical and physiological functions (Tchounwou et al., 2012). Specifically, $\mathrm{Zn}$ is a key factor in a variety of biological processes, as a structural, catalytic, and intracellular and intercellular signalling component (Frassinetti et al., 2006), while $\mathrm{Ni}$, although its biological function is still somewhat unclear, is involved in the maintenance of metabolic homeostasis (Kumar and Trivedi, 2016). Although the essential functions of these metals, their accumulation can cause structural lesions and functional disturbances as an excessive absorption exceeds the detoxifying ability of the organism (Javed and Usmani, 2019). The other essential micro-nutrients analyzed (Cr, Mo, $\mathrm{Se}$, and $\mathrm{Co}$ ) showed different bioaccumulation patterns in the two Antarctic fish evaluated in this study: $\mathrm{Cr}, \mathrm{Mo}$, and $\mathrm{Se}$ decrease significantly from 2002 to 2014 in the red-blooded teleost $T$. bernacchii while in the icefish all three increase significantly and in the case of $\mathrm{Cr}$ reaching values even higher than those of the red-blooded species. The increase of many tested elements in hepatic tissues of both C. hamatus and $T$. bernacchii supports the hypothesis of an increase in environmental concentrations of metal ions from 2002 to 2014.

MTs are proteins able to bind metals and represent an excellent biomarker in the assessment of environmental pollution of these xenobiotics (Brunelli et al., 2011). The induction of metallothionein biosynthesis in fish after metal exposure is well known (Bargelloni et al., 1999; Sinaie et al., 
2010; Wang et al., 2014). Analyzing samples from 2002 to 2014, we observed a significant increase in metallothionein expression in both species. It is also evident that the levels are always higher in $T$. bernacchii than $C$. hamatus leading us to suppose a species-specific response to the presence of metals in seawater. This result could be also in relation of the $\mathrm{Cd}$ accumulation as it is well known that this metal is one of main metallothionein inducers (Price-Haughey et al., 1987; Kovarova et al., 2009; Le Croizier et al., 2018). However, we must not forget that MTs, in addition to their role of homeostasis/detoxification from metals, represent a significant element in maintaining the redox balance of the organism (Sevcikova et al., 2011; Wang et al., 2014; Ma'rifah et al., 2019).

The Antarctic environment, characterized by low seawater temperature and extreme seasonality of light and food supply, makes its organisms more vulnerable compared to temperate species to harmful agents such as metal and reactive oxygen species (ROS). The ROS scavenging function of MTs in Antarctic fish could be very important in relation to the high oxygen partial pressure of their environment. These animals live in cold waters where the dissolved oxygen concentration is very high as a consequence of low temperature that increases gas solubility. Thus, it is possible that the MT system should be involved in the ROS buffering, and in particular in the redblooded species T. bernacchii, which exhibits high levels of MT expression, and consequently had an optimal redox balance, with d-ROM values lower than other seawater fish such as Pagrus major (Hossain et al., 2016). Also the icefish have a low plasmatic level of oxidative stress index despite low values of MT expression. It is probable that in this species the greatest physiological role against the risk of oxidative stress is played by antioxidant enzymes. The enzymatic component of the antioxidant defense system is particularly important in Antarctic fish, which have evolved under selective pressure represented by the constant production of high levels of ROS. Recent studies have shown that the antioxidant enzymes of these fish possess molecular adaptations affecting both their gene structure and the regulation of expression (Sattin et al., 2015; Tolomeo et al., 2016, 2019; Nicorelli et al., 2018; Chatzidimitriou et al., 2020).

\section{REFERENCES}

Ansaloni, F., Gerdol, M., Torboli, V., Fornaini, N. R., Greco, S., Giulianini, P. G., et al. (2021). Cold Adaptation in Antarctic Notothenioids: Comparative Transcriptomics Reveals Novel Insights in the peculiar Role of Gills and Highlights Signatures of Cobalamin Deficiency. Ijms 22, 1812-1822. doi:10.3390/ijms22041812

Bargagli, R. (2000). Trace Metals in Antarctica Related to Climate Change and Increasing Human Impact. Rev. Environ. Contam. Toxicol. 166, 129-173.

Bargagli, R. (2008). Environmental Contamination in Antarctic Ecosystems. Sci. Total Environ. 400, 212-226. doi:10.1016/j.scitotenv.2008.06.062

Bargelloni, L., Babbucci, M., Ferraresso, S., Papetti, C., Vitulo, N., Carraro, R., et al. (2019). Draft Genome Assembly and Transcriptome Data of the Icefish Chionodraco Myersi Reveal the Key Role of Mitochondria for a Life without Hemoglobin at Subzero Temperatures. Commun. Biol. 2. doi:10.1038/s42003-019-0685-y
In conclusion, the present work provides new information on the distribution over time of metal-ions in fish from Antarctica, and is an important contribution to study the responses of these organisms against environmental pollution. In addition, our results provide a general scenario of worldwide pollution, thus supporting the conservation strategies for Antarctic and nonAntarctic habitat protection.

\section{DATA AVAILABILITY STATEMENT}

The raw data supporting the conclusion of this article will be made available by the authors, without undue reservation.

\section{ETHICS STATEMENT}

The animal study was reviewed and approved by the PNRA (National Research Program in Antarctica) CODE 2018/B2Z1.01.

\section{AUTHOR CONTRIBUTIONS}

Conceptualization: AM, DR, and DP; Data curation: AM, DR, and DP; Formal analysis: AM, DR, EB, GS, and DP; Investigation: AM, DR, and DP; Funding acquisition: GS and DP; Methodology: AM, DLR, MFLR, and DB; Project administration: AM, DR, EB, and DP; Resources: AM, DR, and DP; Software: AM, EB, MR, and DP; Supervision: EB, GS, and DP; Validation: EB, GS, and DP; Roles/Writing-original draft: AM, EB, GS, and DP; Writing-review and editing: AM, EB, GS, and DP. All authors reviewed and approved the final manuscript.

\section{FUNDING}

This work was supported by National Research Program in Antarctica (PNRA), AntaGPS project: "Antarctica as a global pollution sensor: aquatic and terrestrial organisms as bioindicators and meta-analysis of pollutant trends" PNRA1800133.

Bargelloni, L., Scudiero, R., Parisi, E., Carginale, V., Capasso, C., and Patarnello, T. (1999). Metallothioneins in Antarctic Fish: Evidence for Independent Duplication and Gene Conversion. Mol. Biol. Evol. 16, 885-897. doi:10.1093/oxfordjournals.molbev.a026178

Beltcheva, M., Metcheva, R., Peneva, V., Marinova, M., Yankov, Y., and Chikova, V. (2011). Heavy Metals in Antarctic Notothenioid Fish from South Bay, Livingston Island, South Shetlands (Antarctica). Biol. Trace Elem. Res. 141, 150-158. doi:10.1007/s12011-010-8739-5

Bervoets, L., Knapen, D., De Jonge, M., Van Campenhout, K., and Blust, R. (2013). Differential Hepatic Metal and Metallothionein Levels in Three Feral Fish Species along a Metal Pollution Gradient. PLoS One 8, e60805. doi:10.1371/ journal.pone.0060805

Brunelli, E., La Russa, D., and Pellegrino, D. (2017). Impaired Oxidative Status Is Strongly Associated with Cardiovascular Risk Factors. Oxidative Med. Cell Longevity 2017, 1-11. doi:10.1155/2017/6480145

Brunelli, E., Mauceri, A., Maisano, M., Bernabò, I., Giannetto, A., De Domenico, E., et al. (2011). Ultrastructural and Immunohistochemical Investigation on the 
Gills of the Teleost, Thalassoma pavo L., Exposed to Cadmium. Acta Histochem. 113, 201-213. doi:10.1016/j.acthis.2009.10.002

Chatzidimitriou, E., Bisaccia, P., Corrà, F., Bonato, M., Irato, P., Manuto, L., et al. (2020). Copper/zinc Superoxide Dismutase from the Crocodile Icefish Chionodraco hamatus: Antioxidant Defense at Constant Sub-zero Temperature. Antioxidants 9, 325. doi:10.3390/antiox9040325

Cimboláková, I., Uher, I., Veszelits Laktičová, K., Vargová, M., Kimáková, T., and Papajová, I. (2020). Heavy Metals and the Environment. Environ. Factors Affect. Hum. Heal. doi:10.5772/intechopen. 86876

Cummings, V. J., Bowden, D. A., Pinkerton, M. H., Halliday, N. J., and Hewitt, J. E. (2021). Ross Sea Benthic Ecosystems: Macro- and Mega-Faunal Community Patterns from a Multi-Environment Survey. Front. Mar. Sci. 8. doi:10.3389/ fmars.2021.629787

Eastman, J. T. (1993). Antarctic Fish Biology. San Diego: Acad. Press. Inc., 274.

El-Moselhy, K. M., Othman, A. I., Abd El-Azem, H., and El-Metwally, M. E. A. (2014). Bioaccumulation of Heavy Metals in Some Tissues of Fish in the Red Sea, Egypt. Egypt. J. Basic Appl. Sci. 1, 97-105. doi:10.1016/j.ejbas.2014.06.001

Flora, G., Gupta, D., and Tiwari, A. (2012). Toxicity of lead: A Review with Recent Updates. Interdiscip. Toxicol. 5, 47-58. doi:10.2478/v10102-012-0009-2

Formigari, A., Boldrin, F., Santovito, G., Cassidy-Hanley, D., Clark, T. G., and Piccinni, E. (2010). Functional Characterization of the $5^{\prime}$-upstream Region of MTT5 Metallothionein Gene from Tetrahymena Thermophila. Protist 161, 71-77. doi:10.1016/j.protis.2009.06.002

Frassinetti, S., Bronzetti, G. L., Caltavuturo, L., Cini, M., and Croce, C. D. (2006). The Role of Zinc in Life: A Review. J. Environ. Pathol. Toxicol. Oncol. 25, 597-610. doi:10.1615/JEnvironPatholToxicolOncol.v25.i3.40

Garofalo, F., Pellegrino, D., Amelio, D., and Tota, B. (2009). The Antarctic Hemoglobinless Icefish, Fifty Five Years Later: A Unique Cardiocirculatory Interplay of Disaptation and Phenotypic Plasticity. Comp. Biochem. Physiol. A: Mol. Integr. Physiol. 154, 10-28. doi:10.1016/j.cbpa.2009.04.621

Garofalo, F., Santovito, G., and Amelio, D. (2019). Morpho-functional Effects of Heat Stress on the Gills of Antarctic T. bernacchii and C. hamatus. Mar. Pollut. Bull. 141, 194-204. doi:10.1016/j.marpolbul.2019.02.048

Hossain, M. S., Koshio, S., Ishikawa, M., Yokoyama, S., and Sony, N. M. (2016). Dietary Nucleotide Administration Influences Growth, Immune Responses and Oxidative Stress Resistance of Juvenile Red Sea Bream (Pagrus major). Aquaculture 455, 41-49. doi:10.1016/j.aquaculture.2016.01.008

Javed, M., and Usmani, N. (2019). An Overview of the Adverse Effects of Heavy Metal Contamination on Fish Health. Proc. Natl. Acad. Sci. India, Sect. B Biol. Sci. 89, 389-403. doi:10.1007/s40011-017-0875-7

Kan, G., Ju, Y., Zhou, Y., Shi, C., Qiao, Y., Yang, Y., et al. (2019). Cloning and Functional Characterization of a Novel Metallothionein Gene in Antarctic SeaIce Yeast (Rhodotorula Mucilaginosa). J. Basic Microbiol. 59, 879-889. doi:10.1002/jobm.201900240

Koppel, D. J., Adams, M. S., King, C. K., and Jolley, D. F. (2019). Preliminary Study of Cellular Metal Accumulation in Two Antarctic marine Microalgae Implications for Mixture Interactivity and Dietary Risk. Environ. Pollut. 252, 1582-1592. doi:10.1016/j.envpol.2019.06.003

Kovarova, J., Kizek, R., Adam, V., Harustiakova, D., Celechovska, O., and Svobodova, Z. (2009). Effect of Cadmium Chloride on Metallothionein Levels in Carp. Sensors 9, 4789-4803. doi:10.3390/s90604789

Kumar, S., and Trivedi, A. V. (2016). A Review on Role of Nickel in the Biological System. Int.J.Curr.Microbiol.App.Sci 5, 719-727. doi:10.20546/ ijcmas.2016.503.084

La Russa, D., Brunelli, E., and Pellegrino, D. (2017). Oxidative Imbalance and Kidney Damage in Spontaneously Hypertensive Rats: Activation of Extrinsic Apoptotic Pathways. Clin. Sci. 131, 1419-1428. Available at: http://www. embase.com/search/results? subaction $=$ viewrecord $\&$ from $=$ export $\&$ id $=\mathrm{L} 617012357 \% 0 \mathrm{~A} 10.1042 /$ CS20170177. doi:10.1042/CS20170177

La Russa, D., Giordano, F., Marrone, A., Parafati, M., Janda, E., and Pellegrino, D. (2019). Oxidative Imbalance and Kidney Damage in Cafeteria Diet-Induced Rat Model of Metabolic Syndrome: Effect of Bergamot Polyphenolic Fraction. Antioxidants 8, 66. doi:10.3390/antiox8030066

La Russa, D., Marrone, A., Mandalà, M., Macirella, R., and Pellegrino, D. (2020). Antioxidant/anti-inflammatory Effects of Caloric Restriction in an Aged and Obese Rat Model: The Role of Adiponectin. Biomedicines 8, 532. doi:10.3390/ biomedicines 8120532
La Russa, D., Montesano, D., Pellegrino, D., Frisina, M., Bagetta, G., Fallarino, F., et al. (2021). Systemic Administration of sunflower Oil Exerts Neuroprotection in a Mouse Model of Transient Focal Cerebral Ischaemia. J. Pharm. Pharmacol. doi:10.1093/jpp/rgab007

Le Croizier, G., Lacroix, C., Artigaud, S., Le Floch, S., Raffray, J., Penicaud, V., et al. (2018). Significance of Metallothioneins in Differential Cadmium Accumulation Kinetics between Two marine Fish Species. Environ. Pollut. 236, 462-476. doi:10.1016/j.envpol.2018.01.002

Macirella, R., and Brunelli, E. (2017). Morphofunctional Alterations in Zebrafish (Danio rerio) Gills after Exposure to Mercury Chloride. Ijms 18, 824. doi:10.3390/ijms18040824

Macirella, R., Guardia, A., Pellegrino, D., Bernabò, I., Tronci, V., Ebbesson, L., et al. (2016). Effects of Two Sublethal Concentrations of Mercury Chloride on the Morphology and Metallothionein Activity in the Liver of Zebrafish (Danio rerio). Ijms 17, 361. doi:10.3390/ijms17030361

Macirella, R., Sesti, S., Bernabò, I., Tripepi, M., Godbert, N., and Brunelli, E. (2019). Lead Toxicity in Seawater Teleosts: A Morphofunctional and Ultrastructural Study on the Gills of the Ornate Wrasse (Thalassoma pavo L.). Aquat. Toxicol. 211, 193-201. doi:10.1016/j.aquatox.2019.04.009

Mahboob, S., Kausar, S., Kausar, S., Jabeen, F., Sultana, S., Sultana, T., et al. (2016). Effect of Heavy Metals on Liver, Kidney, Gills and Muscles of Cyprinus carpio and Wallago Attu Inhabited in the Indus. Braz. Arch. Biol. Technol. 59, 1-10. doi:10.1590/1678-4324-2016150275

Ma'rifah, F., Saputri, M. R., Soegianto, A., Irawan, B., and Putranto, T. W. C. (2019). The Change of Metallothionein and Oxidative Response in Gills of the Oreochromis niloticus after Exposure to Copper. Animals 9, 353. doi:10.3390/ ani9060353

Ndungu, K., Zurbrick, C. M., Stammerjohn, S., Severmann, S., Sherrell, R. M., and Flegal, A. R. (2016). Lead Sources to the Amundsen Sea, West Antarctica. Environ. Sci. Technol. 50, 6233-6239. doi:10.1021/acs.est.5b05151

Nicorelli, E., Gerdol, M., Buonocore, F., Pallavicini, A., Scapigliati, G., Guidolin, L., et al. (2018). First Evidence of T Cell Restricted Intracellular Antigen (TIA) Protein Gene Expression in Antarctic Fish. Invert. Surv. J. 15, 127.

Noyes, P. D., McElwee, M. K., Miller, H. D., Clark, B. W., Van Tiem, L. A., Walcott, K. C., et al. (2009). The Toxicology of Climate Change: Environmental Contaminants in a Warming World. Environ. Int. 35, 971-986. doi:10.1016/ j.envint.2009.02.006

Olsson, P.-E., Kling, P., and Hogstrand, C. (1998). Mechanisms of Heavy Metal Accumulation and Toxicity in Fish. Met. Metab. Aquat. Environ., 321-350. doi:10.1007/978-1-4757-2761-6_10

Perri, A., Lofaro, D., La Russa, A., Lupinacci, S., Toteda, G., Curti, A., et al. (2021). Proinflammatory Profile of Visceral Adipose Tissue and Oxidative Stress in Severe Obese Patients Carrying the Variant Rs4612666 C of NLRP3 Gene. Minerva Endocrinol. 46. doi:10.23736/S2724-6507.21.03460-X

Pilcher, N., Gaw, S., Eisert, R., Horton, T. W., Gormley, A. M., Cole, T. L., et al. (2020). Latitudinal, Sex and Inter-specific Differences in Mercury and Other Trace Metal Concentrations in Adélie and Emperor Penguins in the Ross Sea, Antarctica. Mar. Pollut. Bull. 154, 111047. doi:10.1016/ j.marpolbul.2020.111047

Potapowicz, J., Szumińska, D., Szopińska, M., and Polkowska, Ż. (2019). The Influence of Global Climate Change on the Environmental Fate of Anthropogenic Pollution Released from the Permafrost. Sci. Total Environ. 651, 1534-1548. doi:10.1016/j.scitotenv.2018.09.168

Price-Haughey, J., Bonham, K., and Gedamu, L. (1987). Metallothionein Gene Expression in Fish Cell Lines: Its Activation in Embryonic Cells by 5azacytidine. Biochim. Biophys. Acta (Bba) - Gene Struct. Expr. 908, 158-168. doi:10.1016/0167-4781(87)90055-8

Qu, R., Feng, M., Wang, X., Qin, L., Wang, C., Wang, Z., et al. (2014). Metal Accumulation and Oxidative Stress Biomarkers in Liver of Freshwater Fish Carassius auratus Following In Vivo Exposure to Waterborne Zinc under Different pH Values. Aquat. Toxicol. 150, 9-16. doi:10.1016/ j.aquatox.2014.02.008

Roche, K., Kuta, J., Sedláček, I., Červenka, R., Tomanová, K., and Jurajda, P. (2019). Concentrations of Thirteen Trace Metals in Scales of Three Nototheniid Fishes from Antarctica (James Ross Island, Antarctic Peninsula). Biol. Trace Elem. Res. 191, 214-223. doi:10.1007/s12011-018-1598-1

Russa, D. L., Pellegrino, D., Montesanto, A., Gigliotti, P., Perri, A., Russa, A. L., et al. (2019). Oxidative Balance and Inflammation in Hemodialysis Patients: 
Biomarkers of Cardiovascular Risk? Oxidative Med. Cell Longevity 2019, 1-7. doi:10.1155/2019/8567275

Ruttkay-Nedecky, B., Nejdl, L., Gumulec, J., Zitka, O., Masarik, M., Eckschlager, T., et al. (2013). The Role of Metallothionein in Oxidative Stress. Ijms 14, 6044-6066. doi:10.3390/ijms14036044

Sanchez-Hernandez, J. C. (2000). Trace Element Contamination in Antarctic Ecosystems. Rev. Environ. Contam. Toxicol. 166, 83-127.

Santovito, G., Boldrin, F., and Irato, P. (2015). Metal and Metallothionein Distribution in Different Tissues of the Mediterranean Clam Venerupis Philippinarum during Copper Treatment and Detoxification. Comp. Biochem. Physiol. C: Toxicol. Pharmacol. 174-175, 46-53. doi:10.1016/ j.cbpc.2015.06.008

Santovito, G., Marino, S. M., Sattin, G., Cappellini, R., Bubacco, L., and Beltramini, M. (2012a). Cloning and Characterization of Cytoplasmic Carbonic Anhydrase from Gills of Four Antarctic Fish: Insights into the Evolution of Fish Carbonic Anhydrase and Cold Adaptation. Polar Biol. 35, 1587-1600. doi:10.1007/ s00300-012-1200-9

Santovito, G., Piccinni, E., Boldrin, F., and Irato, P. (2012b). Comparative Study on Metal Homeostasis and Detoxification in Two Antarctic Teleosts. Comp. Biochem. Physiol. Part C: Toxicol. Pharmacol. 155, 580-586. doi:10.1016/ j.cbpc.2012.01.008

Santovito, G., Piccinni, E., and Irato, P. (2008). An Improved Method for Rapid Determination of the Reduced and Oxidized States of Metallothioneins in Biological Samples. Mar. Pollut. New Res., 101-124.

Santovito, G., Trentin, E., Gobbi, I., Bisaccia, P., Tallandini, L., and Irato, P. (2021). Non-enzymatic Antioxidant Responses of Mytilus galloprovincialis: Insights into the Physiological Role against Metal-Induced Oxidative Stress. Comp. Biochem. Physiol. Part C: Toxicol. Pharmacol. 240, 108909. doi:10.1016/ j.cbpc.2020.108909

Sattin, G., Bakiu, R., Tolomeo, A. M., Carraro, A., Coppola, D., Ferro, D., et al. (2015). Characterization and Expression of a New Cytoplasmic Glutathione Peroxidase 1 Gene in the Antarctic Fish Trematomus bernacchii. Hydrobiologia 761, 363-372. doi:10.1007/s10750-015-2488-6

Sevcikova, M., Modra, H., Slaninova, A., and Svobodova, Z. (2011). Metals as a Cause of Oxidative Stress in Fish: a Review. Veterinarni Medicina 56, 537-546. doi:10.17221/4272-VETMED

Sinaie, M., Bastami, K. D., Ghorbanpour, M., Najafzadeh, H., Shekari, M., and Haghparast, S. (2010). Metallothionein Biosynthesis as a Detoxification Mechanism in Mercury Exposure in Fish, Spotted Scat (Scatophagus argus). Fish. Physiol. Biochem. 36, 1235-1242. doi:10.1007/s10695-0109403-x

Tchounwou, P. B., Yedjou, C. G., Patlolla, A. K., and Sutton, D. J. (2012). Heavy Metal Toxicity and the Environment. EXS 101, 133-164. doi:10.1007/978-37643-8340-4_6

Terra, B. F., Araújo, F. G., Calza, C. F., Lopes, R. T., and Teixeira, T. P. (2007). Heavy Metal in Tissues of Three Fish Species from Different Trophic Levels in a Tropical Brazilian River. Water Air Soil Pollut. 187, 275-284. doi:10.1007/ s11270-007-9515-9

Tolomeo, A. M., Carraro, A., Bakiu, R., Toppo, S., Garofalo, F., Pellegrino, D., et al. (2019). Molecular Characterization of Novel Mitochondrial Peroxiredoxins from the Antarctic Emerald Rockcod and Their Gene Expression in Response to Environmental Warming. Comp. Biochem. Physiol. Part C: Toxicol. Pharmacol. 225, 108580. doi:10.1016/j.cbpc.2019.108580

Tolomeo, A. M., Carraro, A., Bakiu, R., Toppo, S., Place, S. P., Ferro, D., et al. (2016). Peroxiredoxin 6 from the Antarctic Emerald Rockcod: Molecular Characterization of its Response to Warming. J. Comp. Physiol. B 186, 59-71. doi:10.1007/s00360-015-0935-3

Twining, B. S., and Baines, S. B. (2013). The Trace Metal Composition of marine Phytoplankton. Annu. Rev. Mar. Sci. 5, 191-215. doi:10.1146/annurev-marine121211-172322

Van der Oost, R., Beyer, J., and Vermeulen, N. P. E. (2003). Fish Bioaccumulation and Biomarkers in Environmental Risk Assessment: A Review. Environ. Toxicol. Pharmacol. 13, 57-149. doi:10.1016/S1382-6689(02)00126-6

Vodopivez, C., Curtosi, A., Villaamil, E., Smichowski, P., Pelletier, E., and Mac Cormack, W. P. (2015). Heavy Metals in Sediments and Soft Tissues of the Antarctic Clam Laternula Elliptica: More Evidence as a ? Possible Biomonitor of Coastal marine Pollution at High Latitudes? Sci. Total Environ. 502, 375-384. doi:10.1016/j.scitotenv.2014.09.031

Wang, W.-C., Mao, H., Ma, D.-D., and Yang, W.-X. (2014). Characteristics, Functions, and Applications of Metallothionein in Aquatic Vertebrates. Front. Mar. Sci. 1. doi:10.3389/fmars.2014.00034

Wani, A. L., Ara, A., and Usmani, J. A. (2015). Lead Toxicity: A Review. Interdiscip. Toxicol. 8, 55-64. doi:10.1515/intox-2015-0009

Wania, F., and Mackay, D. (1996). Peer Reviewed: Tracking the Distribution of Persistent Organic Pollutants. Environ. Sci. Technol. 30, 390A. doi:10.1016/ s0926-3373(97)80026-410.1021/es962399q

Webb, A. L., Hughes, K. A., Grand, M. M., Lohan, M. C., and Peck, L. S. (2020). Sources of Elevated Heavy Metal Concentrations in Sediments and Benthic marine Invertebrates of the Western Antarctic Peninsula. Sci. Total Environ. 698, 134268. doi:10.1016/j.scitotenv.2019.134268

Xu, Q., Chu, Z., Gao, Y., Mei, Y., Yang, Z., Huang, Y., et al. (2020). Levels, Sources and Influence Mechanisms of Heavy Metal Contamination in Topsoils in Mirror Peninsula, East Antarctica. Environ. Pollut. 257, 113552. doi:10.1016/ j.envpol.2019.113552

Conflict of Interest: The authors declare that the research was conducted in the absence of any commercial or financial relationships that could be construed as a potential conflict of interest.

Publisher's Note: All claims expressed in this article are solely those of the authors and do not necessarily represent those of their affiliated organizations, or those of the publisher, the editors and the reviewers. Any product that may be evaluated in this article, or claim that may be made by its manufacturer, is not guaranteed or endorsed by the publisher.

Copyright ( 2021 Marrone, La Russa, Brunelli, Santovito, La Russa, Barca and Pellegrino. This is an open-access article distributed under the terms of the Creative Commons Attribution License (CC BY). The use, distribution or reproduction in other forums is permitted, provided the original author(s) and the copyright owner(s) are credited and that the original publication in this journal is cited, in accordance with accepted academic practice. No use, distribution or reproduction is permitted which does not comply with these terms. 